\title{
蛋白質研究基盤の確立とその薬学分野への応用
}

\author{
井本泰治
}

\section{Foundation of the Bases for Protein Research and Its Application to the Pharmaceutical Science Field}

\author{
Таїі Імото \\ Graduate School of Pharmaceutical Sciences, Kyushu University, Maidashi 3-1-1 \\ Higashi-ku, Fukuoka 812-8582, Japan
}

(Received April 18, 2002)

\begin{abstract}
This paper reviews the results of basic research conducted by the author's group to determine appropriate methods to develop protein-based drugs. These include production strategies, elucidation of physiologic function, improving existing pharmaceuticals, de novo design, and protein reconstruction. The antigenicity of modified proteins and methods to induce antigenic protein tolerance are also described.
\end{abstract}

Key words_—antigenicity; fluctuation; folding; lysozyme; protein; stability; tolerance

\section{はじめに}

著者の研究室で長年行ってきた，蛋白質工学と構 造生物学を中心とした蛋白質研究の基盤確立と, よ り良い蛋白質医薬品を創り出すための基礎を築くた めの努力について紹介する. 我々は独自に分子グラ フィックス, X 線解析, NMR 測定ができる恵まれ た環境でこの研究を推し進めてきた.

特に断らない限り, ニワトリリゾチームを研究材 料に用いた。

\section{1. 蛋白質の大量生産}

まずは大量に蛋白質を生産する事が, 蛋白質を研 究するためにも，また利用するためにも重要であ る. 大量生産系としては大腸菌の系が最も適してい る。我々は 1985 年から遺伝子工学をスタートし た。それまではプライマーを 1 本合成してもらうの に50万円もかかっていた。この頃からやっと DNA 合成機が市販され始め, 我々でも遺伝子工学 を研究に取り込むことができるようになった. 当時 pKK223-3 が市販されている唯一の発現ベクター で，これではリゾチームはほとんど発現できなかっ

九州大学大学院薬学研究院 (T812-8582 福岡市東区馬 出 3-1-1)

*本総説は, 平成 14 年度日本薬学会学術貢献賞の受賞 を記念して記述したものである.
た。そこで発現ベクターの開発から行った. pUC9 系のプラスミドが温度感受的にプラスミドコピー数 を格段に増加させる事を利用して，これの複製起点 ori $\mathrm{p}$ pKK223-3 に導入して pKP1500 という高度発 現ベクターを構築し 1987 年に報告した. ${ }^{1)}$ 発現量は 抜群で，これは世界中に 100 カ所以上発送した。

大腸菌の系は取り扱いが簡単な事, 培養時間が短 い事, 発現量が多い事など, メリットは多いが，大 きなデメリットとして外来性蛋白質はほとんどが変 性蛋白質の封入体として発現され，これを活性な形 に巻き戻すのが至難の技である．この点をクリアー しないと大腸菌の系を大量発現系として利用する事 ができない.

我々が開発した変性蛋白質を効率的にフォルドさ せる方法を紹介する。変性蛋白質は疎水残基が外に 出ており, アグリゲーションを起こしゃすく, そこ で蛋白質の巻き戻しはアグリゲーションとの戦いで ある。一般に用いられる方法が無限大希釈巻き戻し 法である。 ある場合にはこれで効率よく巻き戻せる が, 大量には処理はできない。 そこで, 高濃度での 巻き戻し法を開発すべく努力した。

アグリゲーションを防ぐために，可溶化剂を検討 し，尿素が有効な事にたどり着いた。尿素は優秀な 疎水性物質溶解剂であり, また濃度により蛋白質変 


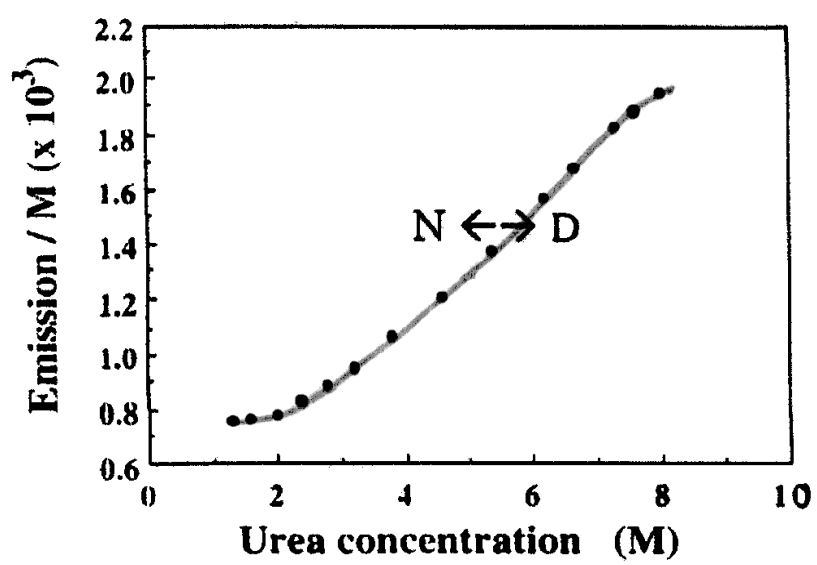

Fig. 1. Native-Denatured Equilibrium of Lysozyme under Red-ox Condition ${ }^{2)}$

性をコントロールできる，巻き戻し条件下でのネイ ティブ $(\mathrm{N})$ と変性 $(\mathrm{D})$ の平衡曲線を Fig. 1 に示し た. ${ }^{2)}$ 尿素濃度を低下させる事で平衡を未変性側へ ずらして行くことができる，ある程度未変性蛋白質 が生成する点で多少の尿素が存在するのでアグリ ゲーションは抑えられる。このカーブの上を滑り降 りて行かせればアグリゲーションを抑えながら巻き 戻しが完成する.

この現象を簡便に実現する方法として，透析法を 開発した (Fig. 2). 蛋白質を $8 \mathrm{M}$ 尿素中で還元後 $8 \mathrm{M}$ 尿素酸化還元系とし，透析バッグに入れて， $8 \mathrm{M}$ 尿素酸化還元液に対して透析を開始する。透析 外液を尿素を含まない酸化還元液で徐々に薄めてい く.かくして $5 \mathrm{mg} / \mathrm{ml}$ という高濃度で $80 \%$ 以上の 高収率で巻き戻せた。 ${ }^{2)}$ ちなみに無限大希釈法では 1/250 の濃度でもこれに及ばない。

リゾチームだからうまく行ったという非難があっ てはならない。そこで，4 本のペプチド鎖からな り, 分子間・分子内に SS 結合を持ち, 分子シャぺ ロンの助けなしには試験管内では巻き戻せないとい われている IgGの巻き戻しに挑戦した（Fig. 3).

ここでは抗リゾチームモノクローナル抗体を用いて 完全に還元し，無限大希釈法で巻き戻したがたしか に巻き戻らなかった (Fig. 3 三角). 分子シャペロ ンの Protein disulfide isomerase（PDI）を用いても ほとんど巻き戻らなかった。しかしながら先の透析 法では能率良く巻き戻り, 驚いた事に高濃度程よく 巻き戻った (Fig. 3 丸). ${ }^{3)}$ このことは, これらの会 合体蛋白質では安定な蛋白分子の形成には会合する

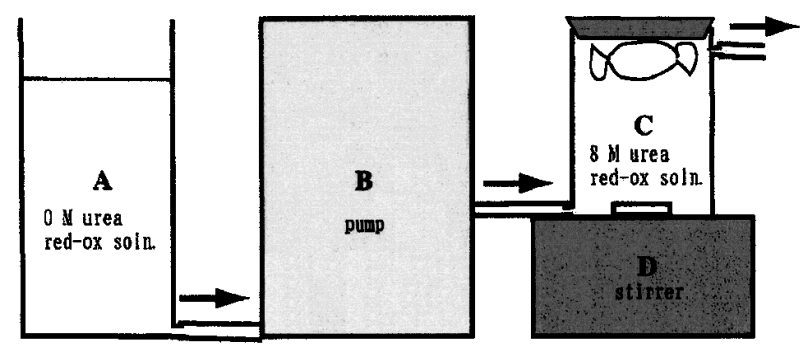

Fig. 2. Equipment for the Slow Dialysis Folding Method ${ }^{2)}$

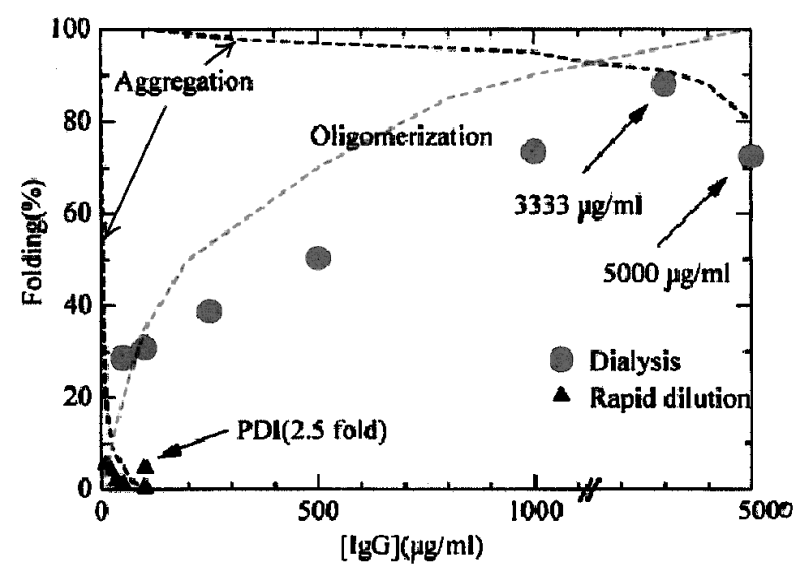

Fig. 3. Folding of IgG (Anti-Lysozyme Monoclonal Antibody) ${ }^{3)}$

事が必要で, そのためにはより高濃度が要求される 事を示している。一方アグリゲーションを抑えるた めには低濃度が要求される。このディレンマのため に従来の巻き戻し法では巻き戻しは不可能であっ た.ところが本法では高濃度で巻き戻す事ができる のでこの問題が解決されたのである。本法は高濃度 蛋白質の巻き戻しを可能とし，会合体蛋白質の巻き 戻しでは特に効果を示す事がわかった。

当然本法は大腸菌に作らせた封入体の巻き戻しに も効果を示した。最近動物細胞を用いる系はバイオ ハザードの問題で大腸菌の系が見直されており，尿 素は安価な試薬で, 本法は工業的な利用にも応用で き，大腸菌の発現系をぐんと有用なものとした.

酵母は活性蛋白質を分泌してくれるので非常に効 果的である. 我々もいろいろと発現系を工夫した が，収率の点で必ずしも満足の行くものではない. せいぜい $5 \mathrm{mg} / \mathrm{l}$ 止まりであった。

最近はPichia 酵母を用いた大量発現系が開発さ れ，効果を示している。これについても我々は種々 の検討を行った. Pichia の場合は染色体 DNAへの 
相同組み込みであり，他の発現系のようなプラスミ ドへの組み达みと異なって複数の組み替え産物がで きる，そこで Pichiaで最も大切な事は，多くの組 換え体の中から最も発現量の多いものを選択する事 である、溶菌班を利用したスクリーニングで我々は $100 \mathrm{mg} / 1$ 以上のリゾチームを発現する変換体を得 た.このような変換体は NMR 測定のための重原子 置換をするための最小培地で培養しても $20 \mathrm{mg} / 1$ の リゾチームを発現し, これは NMR 測定に十分な量 である. ${ }^{4)} こ の$ 結果 NMR の研究を強力に推し進め る事ができるようになった。最近ではカナマイシン でスクリーニングする簡便な方法が開発されている.

\section{2. 生理機能の詳細な解析}

蛋白質が得られるとつぎはその生理機能の詳細な 検討ができる，そこで私のライフワークの1つであ るリゾチームの反応機構の詳細な解析に取り掛つ た. リゾチームの反応機構については既に 1966 年 に Sir D.C. Phillips により基質複合体の X 線解析 の結果から次のようなものが提案された. ${ }^{5)}$ 触媒基 は Glu35 と Asp52 であり，まず，基質 N-アセチル グルコサミン（GlcNAc）の 6 量体が活性クレフト $\mathrm{A}-\mathrm{F}$ にぴったりと結合する. 切断部位である D と $\mathrm{E}$ の糖が触媒基の近傍に固定され，その際に $\mathrm{D}$ 糖 に歪みがはいる. Glu35 はそのプロトンで切断を受 けるグリコシドボンドの酸素に水素結合を作る.こ のプロトンがこの酸素に渡される事で, 切断が起こ り，D糖にカルボニウムイオン中間体が生成す る。このプラスイオンの生成はそばにある Asp52 のマイナスイオンにより安定化される. 一方, 先ほ どの歪みはここで生成するカルボニウムイオンを安 定化する。C1 が sp3 から sp2 になるためにここが 平面構造をとる必要がある. このように遷移状態が 安定化される事によりスムースに反応が進行する. ここで水がはいって加水分解が完了する。これをカ ルボニウムイオン中間体機構と呼ぶ. 最近 Nature にAsp52 がグリコシル結合を作る，グリコシル中 間体を経る機構が提案されたが, $\left.{ }^{6}\right)$ 私は以下に述べ る理由からリゾチームの反応機構はやはりカルボニ ウムイオン中間体機構が主体であると考えている.

Glu35 の方はプロトンドノアーのクリティカル残 基なので Ala に変えることでほぼ完全に失活す る. 7)一方, Asp52のほうは生成するプラスチャー ジをそばで安定化するだけならこの残基を修飾して

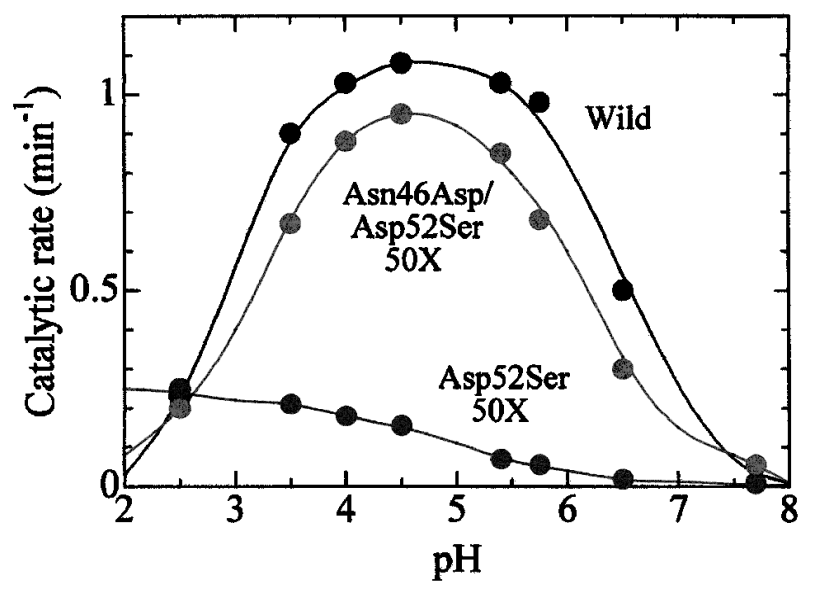

Fig. 4. $\mathrm{pH}$-Dependences of Activity of Lysozyme Derivatives

もそれほどクリティカルに活性が落ちないはずであ る. (GlcNAc) 6 を用いた正確な活性の測定で, 確か

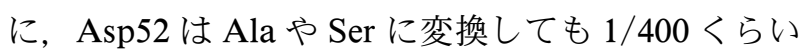
活性が残つた。 ${ }^{8)}$ グリコシル中間体機構では Asp52 はクリティカルなニュクレオフィルで活性が残るは ずはない。このように活性がかなり変動した場合に は構造を確認することがぜひ必要であり，この場合 いずれにおいても構造はほとんど変化がないことを 確認した。我々はほとんどの変異体について X 線 解析による構造確認を行っている.

Figure 4 に示すように, 活性の $\mathrm{pH}$ 依存性で見て も，ネイティブではプロトンを持った形で関与する Glu35 の pK と負電荷で関与する Asp52の pK が見 えている。一方, Asp52 を Ser に変えたものでは活 性が $1 / 400$ に落ちるとともに, Glu35 の pK は見え ているがAsp52 の pK は見えなくなっている。そ ばで生成する正電荷を安定化するだけなら近くにあ りさえすれば位置はそれほど問題にならないはずで ある。そこでAsp52 を Ser に変えて負電荷をつぶ し，近くにあるAsn46 Asp に変えて負電荷の位 置を変換した，すると，Asp46による pKがちゃん と現れ，ネイティブの $1 / 50$ の活性が現れた（Fig. 4）（投稿準備中）。活性が多少低下したのは負電荷 の位置が Asp52に比べて多少遠くなることによ る.このように, Asp52 はマイナスの雾囲気を与え ることで反応に寄与していることが証明された。 Asp46ではAsp52 とは, かなり攻撃位置も変化し ており，又クレオフィリックな攻撃は無理と思われ る. かくしてカルボニウムイオン中間体機構が再確 認された. 

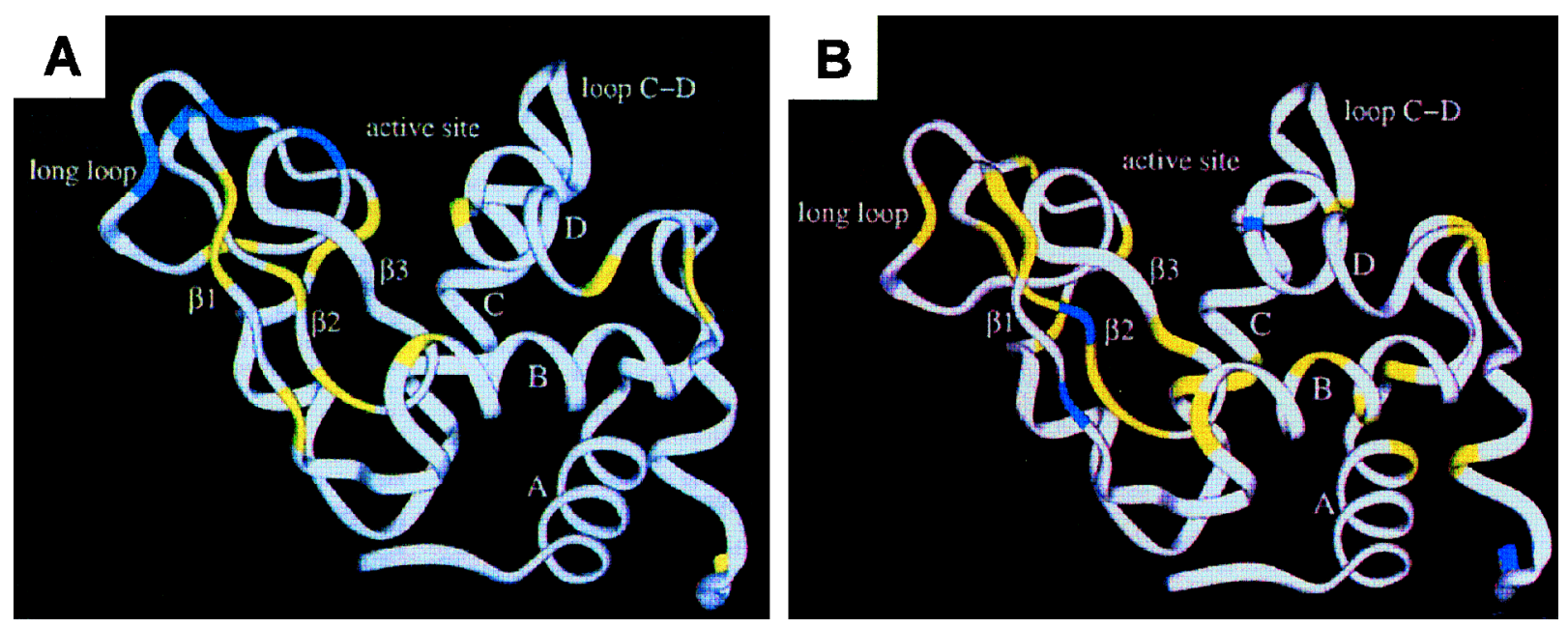

Fig. 5. Fluctuation of Main-Chain Nitrogens in Lysozyme Determined by ${ }^{15} \mathrm{~N}$ Relaxation ${ }^{9)}$

Fluctuation is increased (yellow) or decreased (blue) by forming (GluNAc) ${ }_{3}$-complex. A: Native lysozyme, B: Residues 14,15 deleted lysozyme.

そのほかに，生理機能の詳細な解析結果として， 基質の結合で蛋白質構造の摇らぎがむしろ増加する という驚くべき結果を見出した。これは一様 ${ }^{15} \mathrm{~N}$ 標 識蛋白質の NMR による緩和解析結果から得られ た. 9) Figure 5A で青は複合体の形成で摇らぎが減 少した領域で, 黄色がそれが増加した領域である. 複合体形成で遊離酵素より摇らぎが増加した領域が 多くなっている，後ほど述べるように，この現象は 活性が増加した変異体でより顕著であり, 活性発現 と関連していることが伺える. ニワトリリゾチーム に限らずヒトリゾチーム, ${ }^{10)}$ マウスリゾチームさら にはリボヌクレアーゼ類でもこの現象を確認した。

これは複合体形成による不利なエントロピーロスを 補うために蛋白質の構造の一部の摇らぎを激しくす るのではないかと思われる. 蛋白質の生理現象の発 現にはある種の摇らぎが重要である事を実験的に示 した結果である.

今 1 つ, 蛋白質の生理機能の発現に摇らぎが大切 であることを示す結果が得られた。研究の発端は, 生育温度の異なる菌からの酵素, ここでは 3phosphoglycerate kinase がそれぞれの生育温度に最 適温度を示すが，それぞれがほぼ同等の比活性を示 すという報告を見たことである（Fig. 6). ${ }^{11)}$ 一般に 酵素の活性の温度依存性の立ち上がりは, 触媒基の 活性化エネルギーの温度依存性, 一方高温側の減少 は変性によると考えられている，もしそうであるな ら，これらの酵素は似た活性基を触媒に使ってお

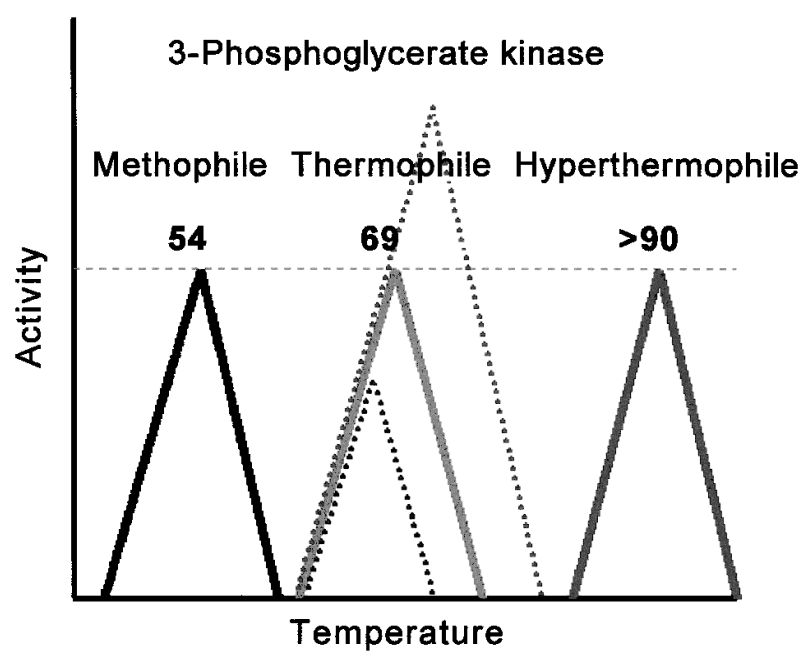

Fig. 6. Temperature-Activity Profiles for Enzymes with Different Stabilities

り, 活性化エネルギーに依存する立ち上がりは等し く, 酵素の安定性に応じて Fig. 6 の点線のような 温度依存性を示すはずである。しかし実情はそうで はない。そこで私はこの活性の立ち上がりは触媒基 の活性化エネルギーのみによるのではなく, むしろ 酵素がその機能を発揮するために必要な摇らぎが実 現できるための温度依存性を示していると考えた. 安定になった酵素は活性を示すに十分な摇らぎを実 現するためには高い温度が必要で, 高い温度で立ち 上がり, 高温で変性する. そのバランスとして比活 性は適当に保たれる.このことは大切なことで, あ まり高い比活性は生命現象維持にむしろ好ましくな 
い. 進化の課程でこれくらいの比活性に保つために も, 安定性と活性発現にこのような相関があること は必要なことである. 低温酵素の場合は逆に, 酵素 は不安定で, 低い温度で機能発現に必要な摇らぎが 実現でき，低い温度で立ち上がり，早く失活する. このような活性の平行移動が実現するのは活性に関 係ある方向での安定化・不安定化が起こった場合で ある. 活性に関係の無い方向での安定化が起こった ときは, 活性発現に必要な摇らぎは影響されないの で, 立ち上がりは変わらず, 変性のみが遅くなつ て，平行移動は起こらず点線のようになる，一方， 活性に関係ない方向で不安定化されると, 立ち上が りは変わらず変性が早く起こる.

この考えを証明するために, 種々に安定性を変動 させたリゾチームの活性の温度依存性を測定した (Fig. 7). ${ }^{12)} 1$ 1-15の間に架橋を入れて安定化した 場合と, His15 をカルボキシメチル化して静電相互 作用の増加で安定化した場合には活性に関係ない方 向での安定化が起こった。一方, Gly104 でニック を入れた場合は不安定化し，これは活性に関係ない 方向での不安定化が起こった. 唯一, 活性に関係あ る方向での不安定化が起こつた例として, Arg14 と His 15 を欠失させた変異体で多少活性の平行移動が 起こつた。これはリゾチームによく似た構造をもつ $\alpha$ ラクトアルブミンに似せて作った変異体である.

この変異体では多少不安定化し, そのため活性に必 要な摇らぎが低温で実現でき, 不安定化のためには やく変性する. Figure 7 の挿入図に示すように 40 ${ }^{\circ} \mathrm{C}$ での活性の増減がこのシフトの指標になる.

Figure 8 にこの変異体の X 線解析結果を黄色で 示し, ワイルドのブルーと重ねあわせた。 ほとんど 構造変化は起こっていない. 欠失の起こった 14,15 部位は活性クレフトの後ろ側にあたり，ここに空間 ができることが, より低温で活性に必要な摇らぎを 実現するのに役立っているものと思われる。 ちなみ に, 残基 15 を種々に変換すると, そのサイズを小

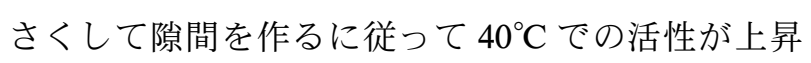
し，低温側に活性の発現がシフトすることが分かつ た (Fig. 9).14, 15 欠失はマイナスのサイズに一致 する. 12)

次いでこの変異体では摇らぎがこの温度領域で増 加したことを示す. 条件をできるだけ合わせて結晶 化し, $1.75 \AA$ の高分解で X 線解析したネイティブ

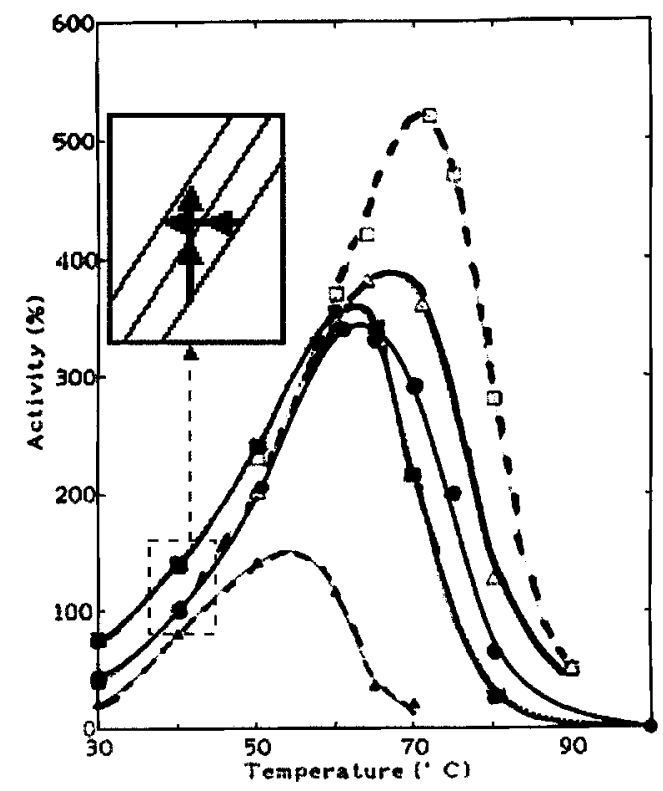

Fig. 7. Temperature - Activity Profiles for Lysozyme Derivatives $^{12}$

Native (closed circle), $1-15$ cross-linked (open square), His 15 carboxymethyl (open triangle), 104 nicked (closed triangle) and residue 14, 15 deleted (closed square).

と 14,15 欠失変異体の温度因子 $\mathrm{B}$ ファクターが欠 失体のほうが大きく遊離酵素で欠失体の方が摇らぎ が大きいことを示している (Fig. 10). 13)

トリプトファンインドール窒素の $\mathrm{H}-\mathrm{D}$ 交換速度 も測定可能であった 4 つ側鎖で比較したところ, 多少欠失体で大きくなり, 特に活性部位にある Trp63 はネイティブに比べてかなり速いことも分か つた. ${ }^{12)}$

さらに先ほどの ${ }^{15} \mathrm{~N}$ 緩和測定の結果, 基質複合体 で遊離酵素より摇らぎが大きくなる部分も, ネイテ イブより欠失体でより広範に及ぶことも分かった (Fig. 5B). ${ }^{9}$

かくして, 蛋白質の生理機能の発現には摇らぎが 大切なこと, 複合体の形成で摇らぎが増大すること など, 蛋白質の生理機能発現と蛋白質構造の摇らぎ に関する重要な知見が得られた。このように蛋白質 が得られると蛋白質の生理機能の詳細な解析ができ る.これは蛋白質を薬として用いるためにも, また 蛋白質を基盤に薬を開発するためにも重要な研究で ある。

\section{3. 蛋白質の性質の向上}

いっそ蛋白質工学的に蛋白質を作るなら, より性 質が向上した蛋白質を作るべきである.より結合力 や活性の上がったものなどいろいろな性質の向上が 


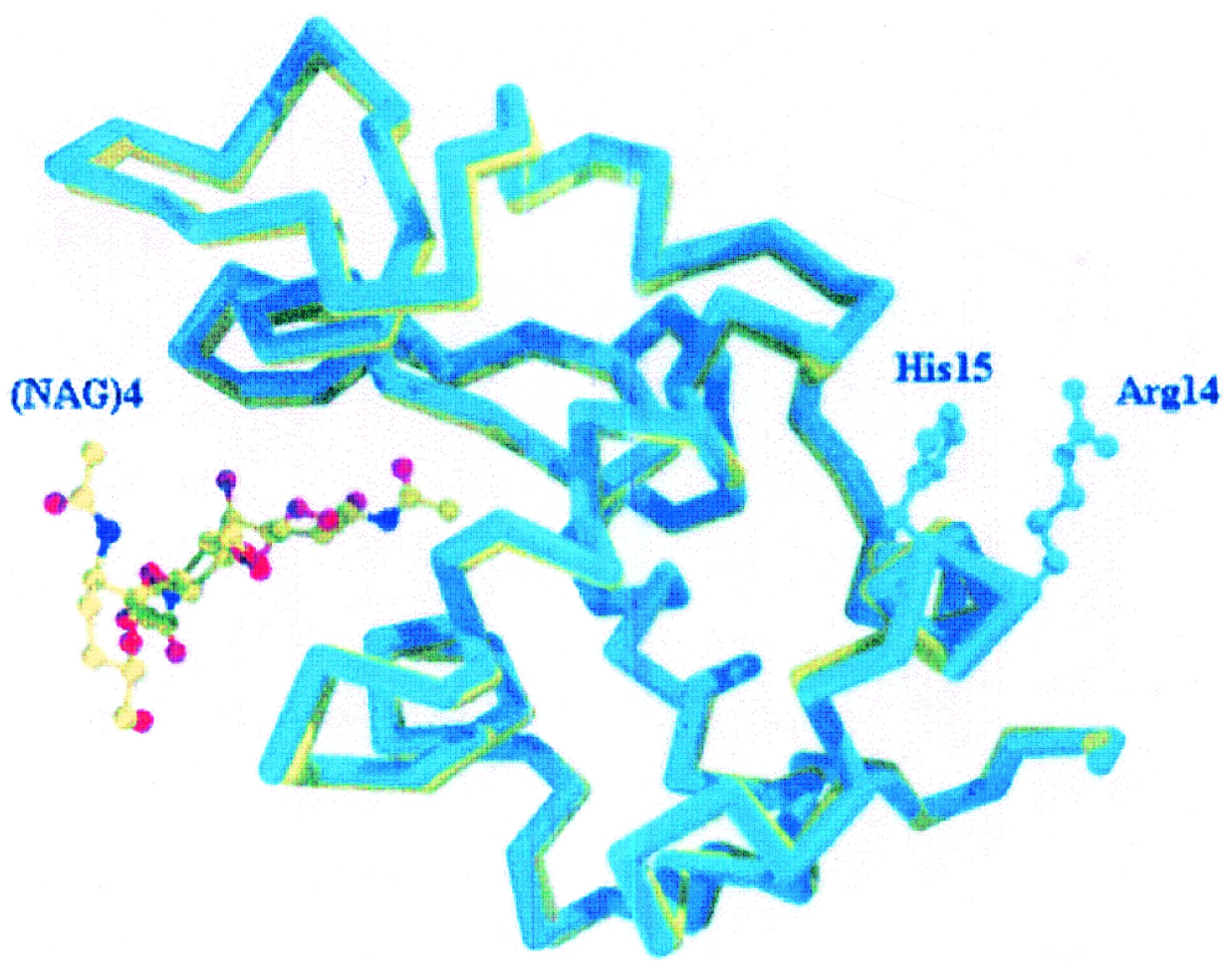

Fig. 8. 3D Structure of Wild Type and Residue 14, 15 Deleted Lysozyme Residue 14,15 deleted lysozyme (yellow) was superimposed on wild type lysozyme (blue).

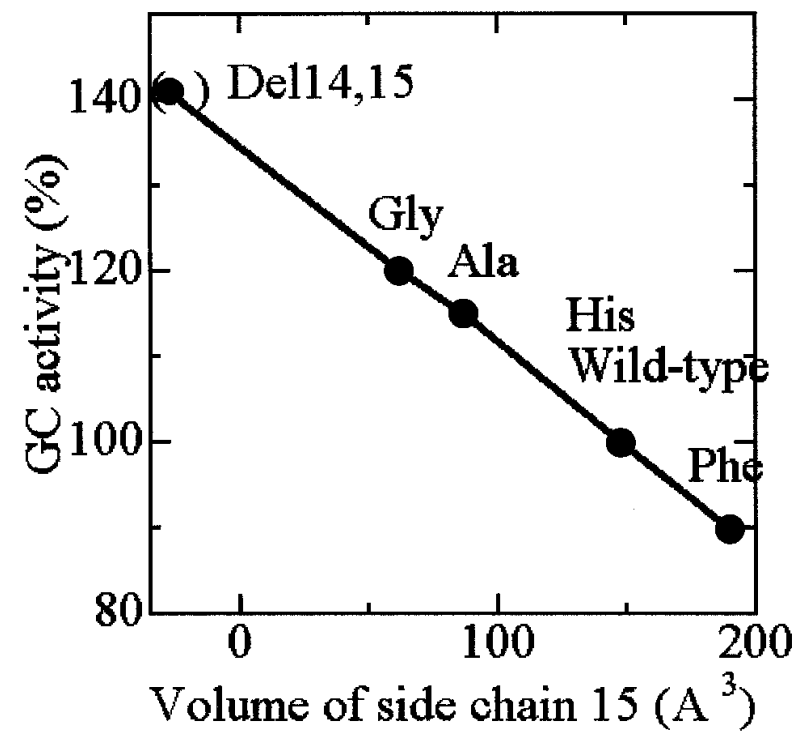

Fig. 9. Volume Dependence on Activity for the His15 Mutants ${ }^{12)}$

各々の蛋白質について考えられる。この分野ではラ ンダム変異や, シャッフリングなどおおいに進展が ある.

普遍的な性質の向上法として安定化がある. 蛋白 質の安定化は重要な問題で蛋白質工学の格好の研究 テーマであり, 我々もかなり幅広く研究を進めてき

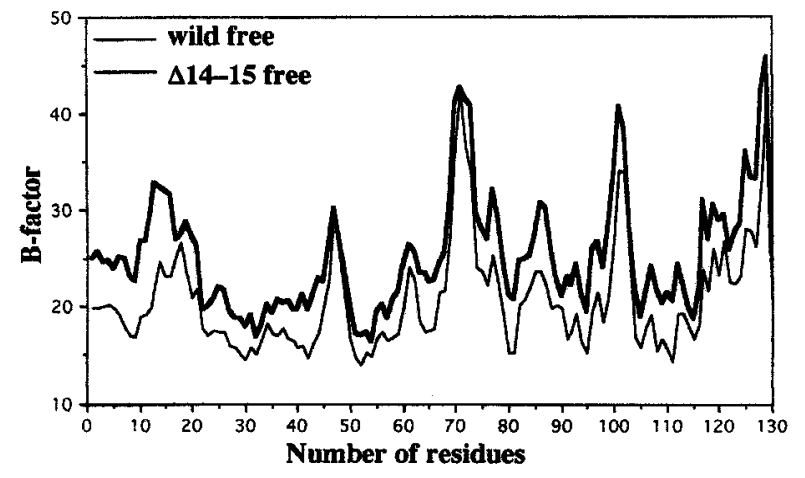

Fig. 10. Plots of B Factor for Main-Chain Atoms of Each Residue in Free Enzymes ${ }^{13)}$

たが，紙面の都合であまり詳しくは紹介できない。 安定化の研究成果については蛋白質の安定化に関す る筆者の総説14)を参照ください.

一般に平衡論的（熱力学的）安定化がなされる. 安定化すると, 蛋白質は使いやすくなり, 特に高温 で使えるようになると高い活性を取り出すことがで きる。一般に蛋白質は非常に不安定に作られてお り，容易に安定化できる。多くの研究がなされてお り，我々も種々の検討を行ってきた. 
一例だけ，化学修飾により架橋を施して安定化し た珍しい例で説明する．2 価性の架橋剂で Lsy1 と His 15 の間を架橋すると変性転移温度が 5 度上が る。一方，ヨードによる酸化反応で, Glu35 と Trp108 の間にエステル結合架橋を施すことができ る。この結果リゾチームは 14 度も安定になる。こ の架橋を同時に入れると，20 度も安定なリゾチー

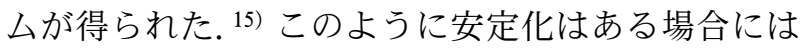
加算的に重ね合わせることができ，いくらでも安定 にできる.

我々はこのような平衡的すなわち, 熱力学的安定 化と共に, 速度論的安定化の重要性について強調し てきた. プロテアーゼ消化などの変性状態に共役し た不可逆変性の場合には，プロテアーゼ濃度がある 程度高くなると, 変性蛋白質は直ちに分解され, 変 性蛋白質が生成してくる速度が律速となる。このよ うな場合, 平衡的な安定化より, 変性蛋白質が生成 し難いように速度論的に安定化する事が必要とな る. すなわち, 変性速度を小さくするような安定化 が必要となる.この安定化は特に薬学領域での薬と しての蛋白質の利用で大切である. 我々はこの速度 論的な安定化の方法論についても種々検討した. そ の方法論は先の総説に述べたが, ${ }^{14)}$ プロテアーゼ消 化に対して安定になるようにチェックしながら安定 化することが簡便な速度論的な安定化法である.

一方, 得体の知れない変性として, 長期使用, 長 期保存中に起こる蛋白質の劣化に対する安定化につ いて研究した.これは薬としての蛋白質の保存に対 して重要である。1 100 度に保つことで長期保存を短 時間でシミュレートできる. 蛋白質の劣化は, デア ミデーション，アミノ酸残基のラセミ化や異性化, ペプチド結合の切断, SS 結合の切断や掛け違いな どの, 種々の化学反応が蓄積してその蛋白質が活性 構造を保てなくなり, 変性するために失活する事で 起こることを突き止めた. ${ }^{16)}$

これに対する対応策についても種々検討した。化 学反応が起こらないように, 緩衝液を選択する. 広 く使われているリン酸緩衝液もあまりよくない. $\mathrm{pH}$ を微酸性に保つことも大切である. ${ }^{17)}$ 今 $1 つ$ は，蛋白質を安定化することで劣化を抑えることが できる. SS 結合を 1 本切って不安定化すると劣化 は早くなり，架橋を入れて安定化すると劣化は抑え られる。化学反応は一般に変性状態で起こり, 安定
化で変性状態の確率が減ることで化学反応が抑えら れる. 一方, より多くの化学反応を受けても蛋白質 は安定化により活性構造を保つことができる. かく して安定化は二重に劣化を抑えることになる.

このように，同じ安定化と言ってもそれぞれの目 的に応じた方策を施す必要がある.

\section{4. 新規機能性蛋白質の創製}

蛋白質工学の最終目標は目的の機能性蛋白質をデ ザインして創製する事である. 我々は今や最終構造 をもくろんで一次構造をデザインする事は可能とな つた。しかしながら, 現実には, その蛋白質をフォ ルドさせる事ができずアグリゲーションしてしま う。これはいつに我々がフォルディングの情報を持 ち合わせていないからである。この情報の収集なし に蛋白質の de novo デザインはありえない. 天然 の蛋白質はひとりでに巻き上がり, そのように進化 してきた。 そこで天然の蛋白質はフォルディングの 情報を持っている，我々はこれを読み出すべくリゾ チームで種々の研究を推し進めている.

ランダム変異体からフォルディングできないもの を選び出し検討したり， リゾチームの 59 から 105 のフラグメントがそれ自体でフォルドできることを 見出し, ${ }^{18)}$ このフラグメントでフォルディングを検 討している. 理由は, 小さい方が研究しやすいこ と. 蛋白質は頑強にできていて別のルートで強引に 巻き上がるのでフォルディングのファインな情報を 取り出すのはフラグメントのほうが都合がよいから である.これらの研究の行程で, Trp62がフォルデ イングに大きな影響を持つことが浮き彫りになって きた. Trp62酸化リゾチームが還元再生でネイティ ブとは多少異なる構造に帰結する. ${ }^{19)}$ Trp62Gly 変 異リゾチームの再生にネイティブにないタイムラグ が生じる (投稿準備中). さらにペプチドフラグメ ントの実験で Trp62 を切り取ることでそれまでう まくいっていた SS 結合の生成に掛け違いが起こる ようになる. ${ }^{18)}$ ネイティブ構造では外に飛び出して いる Trp62 がごうしてこれほどフォルディングに クリティカルであるのか理解できなかった.

最近ドイツの Schwalbe 博士との共同研究でこの 答えが見つかつた。 ${ }^{20)}$ NMR の緩和実験からリゾ チームはSS 結合を切断した変性状態でいくつかの 領域でクラスターを作っているように見えていた (Fig. 11B)。ところが Trp62 たつた 1 残基を Glyに 


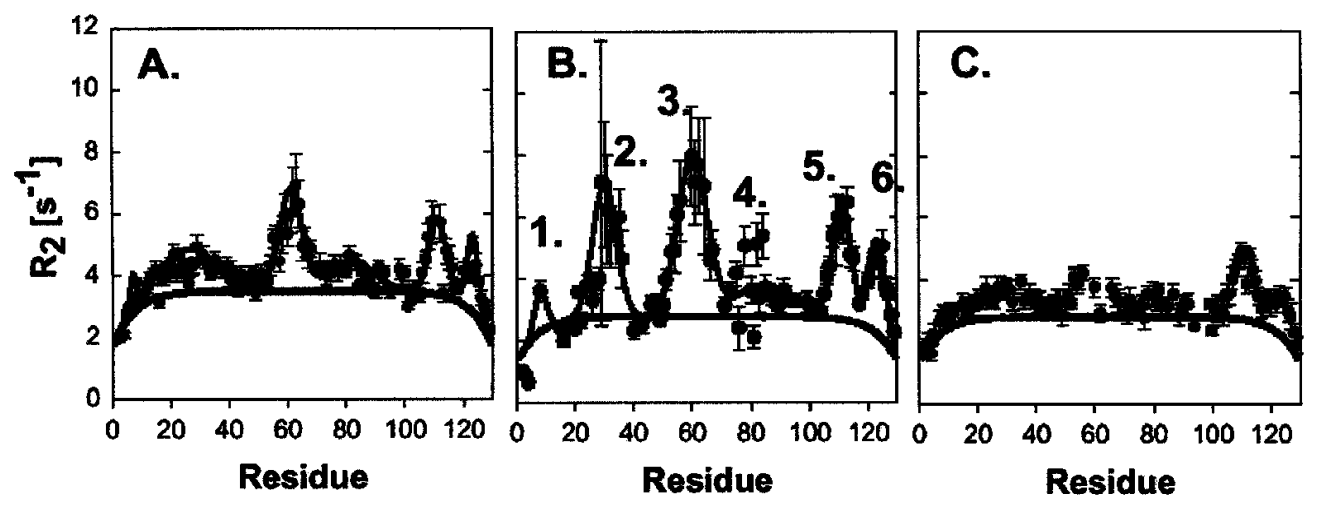

Fig. 11. Comparison of ${ }^{15} \mathrm{~N}$ Transverse Relaxation Rates $\mathrm{R}_{2}$ in Hen Lysozyme ${ }^{20)}$

S-Methylated lysozymes at $\mathrm{pH}$ 2. Wild type lysozyme in $8 \mathrm{M}$ urea (A) and $0 \mathrm{M}$ urea (B). Trp62Gly mutant in 0M urea (C).

変換した変異体でこのクラスターが一気に消失する と言う驚くべき事実を見出した（Fig. 11C）。この ことはこれらのクラスターがいくつかの領域ででき ているのではなく実は 1 つの大きなクラスターを形 成しており, Trp62がそのコアー残基として変性構 造形成に関与していたことがわかつた。このように フォルディングの研究で変性構造を知ることの重要 性が明確になった。それと共に変性構造は最近とみ に問題となっているコンフォーメーショナルディ ジーズの解明にも必要な情報である.

\section{5. 蛋白質の機能変換}

フォルディング情報の解読にはいま少し時間がか かりそうな事, 次に述べる抗原性の問題等を考慮し て, 既存の蛋白質, 特にヒト型蛋白質を土台に改変 により目的の機能を持つ蛋白質を創り出す事も現段 階では, 必要な逃げ道かと思われる. 既存の蛋白質 には巻き戻しの情報が組み込まれていること，ヒト 型の蛋白質であれば抗原性が軽減されることが期待 されるからである。そこで, 既存蛋白質の再構築の 基盤を築くことが必要となる.

その手始めとして, リゾチームの反応機構をカル ボニウムイオン中間体機構からグリコシル結合中間 体機構へと反応機構の変換を試みた. 生成するカル ボニウムイオンの近傍で負電荷を提供して安定化し ている Asp52を Glu に変換して, カルボキシル基 をもつと反応点に近づけるとグリコシル中間体が生 成することが期待される。確かに安定なグリコシル 中間体が生成し，X 線で検出することができた. ${ }^{21)}$ しかしこれは安定過ぎてターンオーバーが非常に悪 いことがわかった。このことからもリゾチームには
グリコシル中間体を能率的にターンオーバーする機 構は組み込まれていない。これを分解する触媒基と して近傍の Asn46 Asp に変換すると, ある程度 ターンオーバーするようになる. ${ }^{22)} \mathrm{Asp} 52$ を Ser に 変換した後, Asn46 G Glu として基質に近づける と，確かにグリコシル中間体は生成するがこれは無 理な構造のためそれほど安定でなく, 適当にターン オーバーする.このようにすることで, ネイティブ リゾチームの正常な反応の $1 / 10$ 位の活性が出る. かくしてリゾチームの反応機構をカルボニウムイオ ン中間体機構から，グリコシル中間体機構へと変換 する事ができた。

\section{6. 抗原性と免疫寛容}

蛋白質工学的手法による蛋白質修飾の方法を述べ てきた。 ヒトの蛋白質を土台とすれば抗原性も多少 軽減されるのではないかというような便法の話もし てきたが，やはり薬として蛋白質を使う場合は抗原 性の問題は気になるところである。そこで自己蛋白 質にどれほどの変異を入れれば抗原となるのかを検 討した。

外来抗原であるニワトリリゾチームと自己蛋白質 であるマウスリゾチームの間のホモロジーは $57 \%$ とかなり差が有る. BALB/c マウスを用いた場合, 当然外来性抗原であるニワトリリゾチームに対して は抗体ができる，自己蛋白質のマウスリゾチームに 対しては抗体は生産されないが, マウスリゾチーム にたった 3 残基の変異（Ala114Asn/His115Arg/ Gln117Lys）を入れてニワトリリゾチームに近づけ た場合，自己蛋白質が抗原となることがわかつ

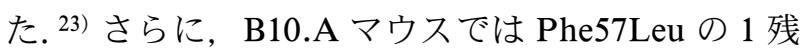


基変異でマウスリゾチームに対する抗体が生産され た. ${ }^{24)}$ かくして例え 1 残基変異であっても自己蛋白 質が抗原となり得ることが証明された。新規にデザ インした蛋白質は当然抗原であり, 例えマイナーな 修飾でも抗原となり得る可能性が示された。 さら に，ヒトそのものの蛋白質でも医薬として処方する と抗原性が出ることも見出されている.このような 状況で, 蛋白質に抗原性を失わせること, すなわち 免疫寛容を与える方策を見出すことはとてつもなく 重要なことである.

そこで最後に免疫寛容の話に入る.ここからは抗 原としてニワトリリゾチームを用いる，まずは，蛋 白質を安定にすることで試験管内 $\mathrm{T}$ 細胞刺激を抑 制できることを証明した. ${ }^{25)}$ リゾチーム特異的なモ ノクローナル $\mathrm{T}$ 細胞ハイブリドーマの刺激がリゾ チーム誘導体の安定性と相関している. 不安定な誘 導体ほど $\mathrm{T}$ 細胞刺激を容易に行い, 安定なものは 刺激能が低い.

ついで, 安定化の方法として, ポリエチレングリ コール修飾を用いた（Fig. 12）。未修飾リゾチーム では十分に抗体が生産される処理で, PEG 修飾リ ゾチームでは全く抗体生産が起こらなかった。 その 上, 引き続き未修飾リゾチームを投与しても全く抗 体生産は見られなかった。 PEG 修飾リゾチームが リゾチームに対する免疫寛容を引き起こしたことに なる. ${ }^{26)}$

以後用いた免疫寛容の程度を見るプロトコールは 次のようなものである. 寛容源で処理後寛容誘導 7 日間，ついで，ネイティブニワトリリゾチームとフ ロイントの完全アジュバントで強く免疫し 9 日間免 疫惹起した後, $\mathrm{T}$ 細胞応答と血清抗体応答を測定し た. PEG 修飾リゾチーム処理した場合は, ニワト リリゾチームで強く免疫をかけたにもかかわらず, ニワトリリゾチームで刺激される $\mathrm{T}$ 細胞の増殖も 少なく, ニワトリリゾチームに対する抗体もほとん ど生産されない. 免疫寛容を引き起こすための最適 PEG 修飾率を調べたところ大体蛋白分子量の 1.5 2 倍量の PEG 修飾が最適であることがわかつた. ${ }^{27)}$

ついで, 免疫寛容が起こる原因について検討し た．抗原の血中残存量が関係することがわかつ た. ${ }^{28)}$ 未修飾リゾチームが 1 日で検出限界以下に低 下するのに比べて, PEG 修飾リゾチームでは, 28 日間も残存する（Fig. 13A）。7日目に，それぞれ

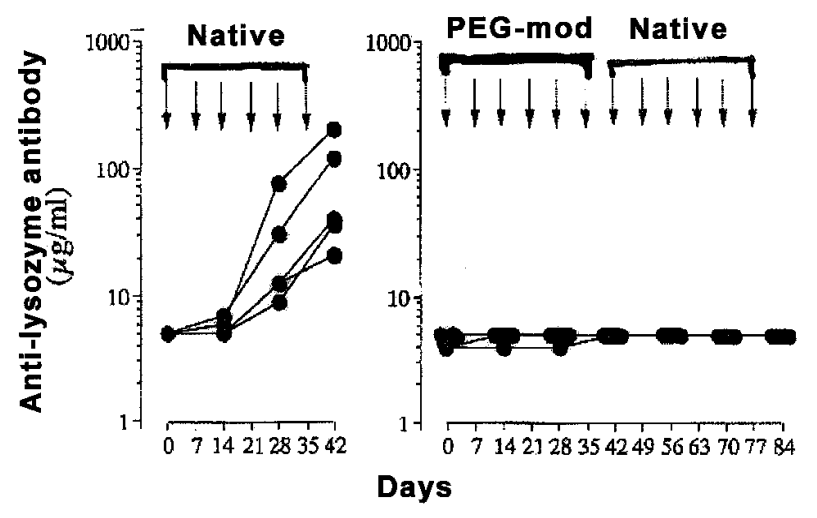

Fig. 12. Inhibition of Anti-Lysozyme Antibody Production by Pretreatment with PEG-Lysozyme Injection: 100 micro gram/mouse.
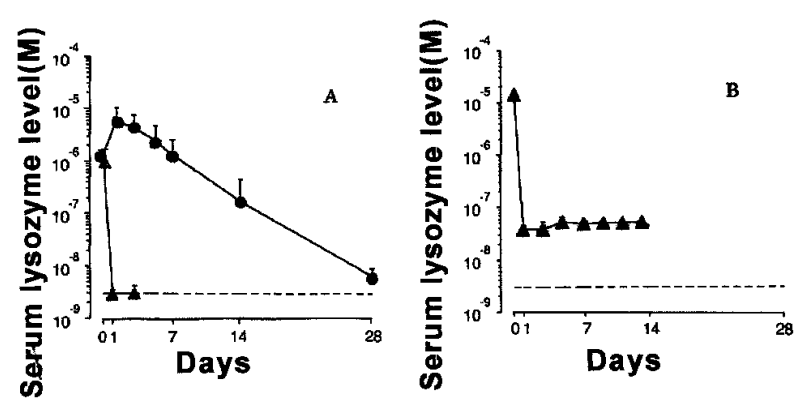

Fig. 13. Blood Clearance Profiles for Lysozyme Derivatives $^{28)}$

A: Native lysozyme (closed triangle) and PEG-lysozyme (closed circle); $1 \mathrm{mg} / \mathrm{mouse}$. B: Native lysozyme $10 \mathrm{mg} / \mathrm{mouse} /$ day (closed triangle).

の $\mathrm{T}$ 細胞増殖と抗体価を測定した。未修飾リゾ チームに比べ PEG 修飾リゾチームではほぼ完全に 免疫反応は抑えられている. PEG 修飾リゾチーム の場合も，その血中濃度が低下する 28 日以降には 免疫寛容現象がとかれてくる. しかもこの後, 再度 GEG 修飾リゾチームで刺激すると寛容が誘導され る. かくして, 抗原の血中残存が免疫寛容の原因に なっていることが伺えた.

それなら，未修飾リゾチームでも血中に残存する ように大量に打ち続けると寛容が起こるのかを調べ た (Fig. 13B). $10 \mathrm{mg} /$ day も打ち続けると血中濃 度は維持され，7 日目で測定すると免疫寛容現象が 明らかに成立していた。

蛋白質を安定にして, 血中濃度を長期間あるレベ ルに保たせるとその蛋白質に対して免疫寛容が成立 する可能性を示すことができた。このことは蛋白質 
の医薬としての利用に対して無限の可能性を示すも のである.

\section{おわりに}

以上が，我々が蛋白質研究の基盤を築き，よりよ い蛋白質医薬品を創製するために行ってきた努力の 概要である.

\section{謝辞ここの研究を遂行するに当たり多くの方々} のご尽力を得ました，厚くお礼申し上げます，東大 の嶋田一夫先生には NMR のご指導はもとより, 多 くの局面で大変お世話になりました，九大の三木健 良先生には遺伝子工学の導入に関して，また X 線 解析の導入に関しては, 名大の山根隆先生, 京大の 畑安雄先生にお世話になりました。NMR に関して は富山医薬大の河野敬一先生, 生物工学究所の楯真 一先生，九大の神田大輔先生にご指導を受けまし た.この研究は九大免疫薬品学研究室のスタッフ, 学生の絶え間ない努力の賜物であると深く感謝いた します。

\section{REFERENCES}

1) Miki T., Yasukochi T., Nagatani H., Furuno M., Orita T., Yamada H., Imoto T., Horiuchi T., Protein Eng., 1, 327-332 (1987).

2) Maeda Y., Koga H., Yamada H., Ueda T., Imoto T., Protein Eng., 8, 201-205 (1995).

3) Maeda Y., Ueda T., Imoto T., Protein Eng., 9, 95-100 (1996).

4) Mine S., Ueda T., Hashimoto Y., Tanaka Y., Imoto T., FEBS Lett., 488, 33-37 (1999).

5) Phillips D. C., Sci. Amer., 215, 78-90 (1966).

6) Vocadlo D. J., Davies G. J., Laine R., Withers S. G., Nature., 412, 835-838 (2001).

7) Inoue M., Yamada H., Hashimoto Y., Yasukochi T., Hamaguchi K., Miki T., Horiuchi T., Imoto T., Biochemistry, 31, 8816-8821 (1992).

8) Hashimoto Y., Yamada K., Motoshima H., Omura T., Yamada H., Yasukochi T., Miki T., Ueda T., Imoto T., J. Biochem., 119, 145150 (1996).

9) Mine S., Tate S, Ueda T., Kainosho M., Imoto T., J. Mol. Biol., 286, 1547-1565 (1999).

10) Mine S., Ueda T., Hashimoto Y., Imoto T., Protein Science, 9, 1669-1684 (2000).

11) Varley P. G., Pain R. H., J. Mol. Biol., 220,
531-538 (1991).

12) Imoto $T$., Ueda $T$. , Tamura $T$., Isakari $Y$. , Abe Y., Inoue M., Miki T., Kawano K., Yamada H., Protein. Eng., 7, 743-748 (1994).

13) Ohmura T., Motoshima H,., Ueda T., Imoto T., J. Biochem. in press (2002).

14) Imoto T., Cell. Mol. Life Sci. (Experientia), 53, 215-223 (1997).

15) Ueda T., Masumoto K., Ishibashi R., So T., Imoto T., Protein Eng., 13, 193-196 (2000).

16) Tomizawa H., Yamada H., Imoto T., Biochemistry, 33, 13032-13037 (1994).

17) Tomizawa H., Yamada H., Wada K., Imoto T., J. Biochem., 117, 635-640 (1995) .

18) Ueda T., Ohkuri T., Imoto T., Biochem. Biophys. Res. Commun., 228, 203-208 (1996).

19) Ueda T., Abe Y., Ohkuri T., Kawano K., Terada Y., Imoto T., Biochemistry, 34, 1617816185 (1995).

20) Kline-Seetharaman J., Oikawa M., Grimshaw S. B., Wirmer J., Duchardt E., Ueda T., Imoto T., Smith L. J., Dobson C. M., Schwalbe H., Science, 295, 1719-1722 (2002).

21) Kuroki R., Ito Y., Kato Y., Imoto T., J. Biol. Chem., 272, 19976-19981 (1997).

22) Ito Y., Kuroki R., Ogata Y., Hashimoto Y., Sugimura K., Imoto T., Protein Eng., 12, 327 -331 (1999).

23) Tsujihata Y., So T., Chijiiwa Y., Hashimoto Y., Hirata M., Ueda T., Imoto T., J. Immunol., 165, 3605-3611 (2000).

24) Tsujihata Y., So T., Hashimoto Y., Ueda T., Imoto T., Mol. Immunol., 38, 375-381 (2001).

25) So T., Ito H.-O., Koga T., Watanabe S., Ueda T., Imoto T., J. Biol. Chem., 272, 32136 -32140 (1997).

26) Ito H.-O., So T., Hirata M., Koga T., Ueda T., Imoto T., Immunology, 93, 200-207 (1998).

27) So T., Ito H.-O., Tsujihata Y., Hirata M., Ueda T., Imoto T., Protein Eng., 12, 701-705 (1999).

28) So T., Ito H.-O., Hirata T., Ueda T., Imoto T., Cell. Mol. Life Sci. (Experientia), 55, 1187-1194 (1999). 